\title{
Application of Geographic Information System (GIS) in Mapping Groundwater Quality in Uyo, Nigeria
}

\author{
Magnus Uzoma Igboekwe*, Akaninyene Okon Akankpo \\ Department of Physics, Michael Okpara University of Agriculture,Umudike, Abia State, Nigeria \\ E-mail: ${ }^{*}$ igboekwemu@yahoo.com
}

Received June 2, 2011; revised August 17, 2011; accepted September 24, 2011

\begin{abstract}
In recent years there has been serious concern on the deteriorating groundwater quality due to the activities of man. Geographic Information System (GIS), a high performance computer based tool is playing a critical role in water resource management and pollution study. In this work, the GIS software was used to analyze the effects of various data layers (topographic slope, groundwater table variation, soil porosity and land use activities) on the distribution of groundwater pollution in the Nigerian city of Uyo. Spatial variability map of different groundwater quality parameters were generated using interpolation operation in the software. A good correlation exists between some of the pollution indicators (total dissolved solids, TDS and conductivity, CN, 0.8; chloride and TDS, 0.17 as well as TDS and sulphate, 0.23 ). The results of spatial variability maps of different groundwater quality parameters indicate an increase in the percentages of pollution levels during the last five years. Cross operation was also used to explain the effects of various data layers viz. topographic slope, groundwater slope, depth to groundwater layer and land use activities on the distribution of groundwater pollution.
\end{abstract}

Keywords: Groundwater, Pollution, Water Quality, GIS, Uyo Urban

\section{Introduction}

Of all the natural resources, water permeates perhaps most deeply into all aspects of life. Water is no doubt one of the most essential needs of human beings, for drinking and other domestic purposes. Its presence or lack of it determines to a great extent the nature of the natural environment in which life and majority of our economic activities depend on [1].

Water is a landscape element and as a chemically active mobile substance, it is always on contionous move through the surface and subsurface of the earth. Groundwater constitutes over $90 \%$ of the world's readily available freshwater resources with the remaining $10 \%$ in lakes, reservoirs, rivers and wetlands [2]. Though groundwater is generally of good quality, quality problems do occur. More serious than natural pollution is contamination from the activities of man.

Groundwater is inherently succeptible to contamination from anthropogenic activities and remediation is very expensive and sometimes not practical. Frequently handling of polluting substances on the ground surface involve interventions with water quality, in view of the fact that water is an excellent solvent, chemically active, and always on the move according to the laws controlling the hydrodynamics of the water cycle. Once caught by the moving groundwater, pollutants therefore tend to move along with groundwater, unless chemical reactions along the groundwater pathways influence the mobility of the pollutant.

Geographic Information System (GIS), a high performance computer based tool is playing a critical role in water resource management and pollution study. GIS represents a technological advancement in terms of overlay mapping techniques. It is a latest tool available to store, retrieve and analyse different types of data for management of water resources. It facilitates systematic handling of data to generate information in a devised format. GIS has advantages over traditional methods used in groundwater studies. They include effective storage and analysis system for spatial and temporal database, graphical presentation, visual impacts and spatial distribution of graphical outputs on water guality changes, pollution load and relationship with sources.

The integrated land and water information system (ILWIS 2.2) is a low cost PC-based GIS software that in- 
tegrates conventional GIS techniques, digital image processing and raster based spatial modeling. As a GIS package, ILWIS allows a user to input, manage, analyze and present geographic data.

It can also generate information from the data on spatial and temporal patterns and processes it on the earth surface. It is used in land evaluation, environmental management, and natural risks assessment [3].

In Uyo Urban the Akwa Ibom State capital, groundwater remains the most readily available source of water to the residents. Groundwater quality assumes much greater emphasis in such situation, as quality of existing groundwater resources cannot be allowed to deteriorate further. This study focuses on mapping groundwater pollution with respect to certain significant groundwater quality parameters. It also assesses the variations of these pa- rameters over a period of five years, using Geographic Information System (GIS).

\section{The Study Area}

Uyo is situated between latitude $5^{\circ} 01^{\prime}$ "North of Equator and longitude $7^{\circ} 56^{\prime}$ East of the meridian. Figure 1 shows the location map of the study area. The sub-equatorial climate region is influenced by warm humid air masses from the Atlantic Ocean and slightly by the hot day air masses called harmattan. The area enjoys the influence of maritime all the year round. Rainy season occurs between March and October with a short dry season from November to February. The area has mean annual rain- fall of $2484 \mathrm{~mm}$ and a mean yearly temperature of $27^{\circ} \mathrm{C}$. It has relative humidity range of $70 \%-80 \%$.

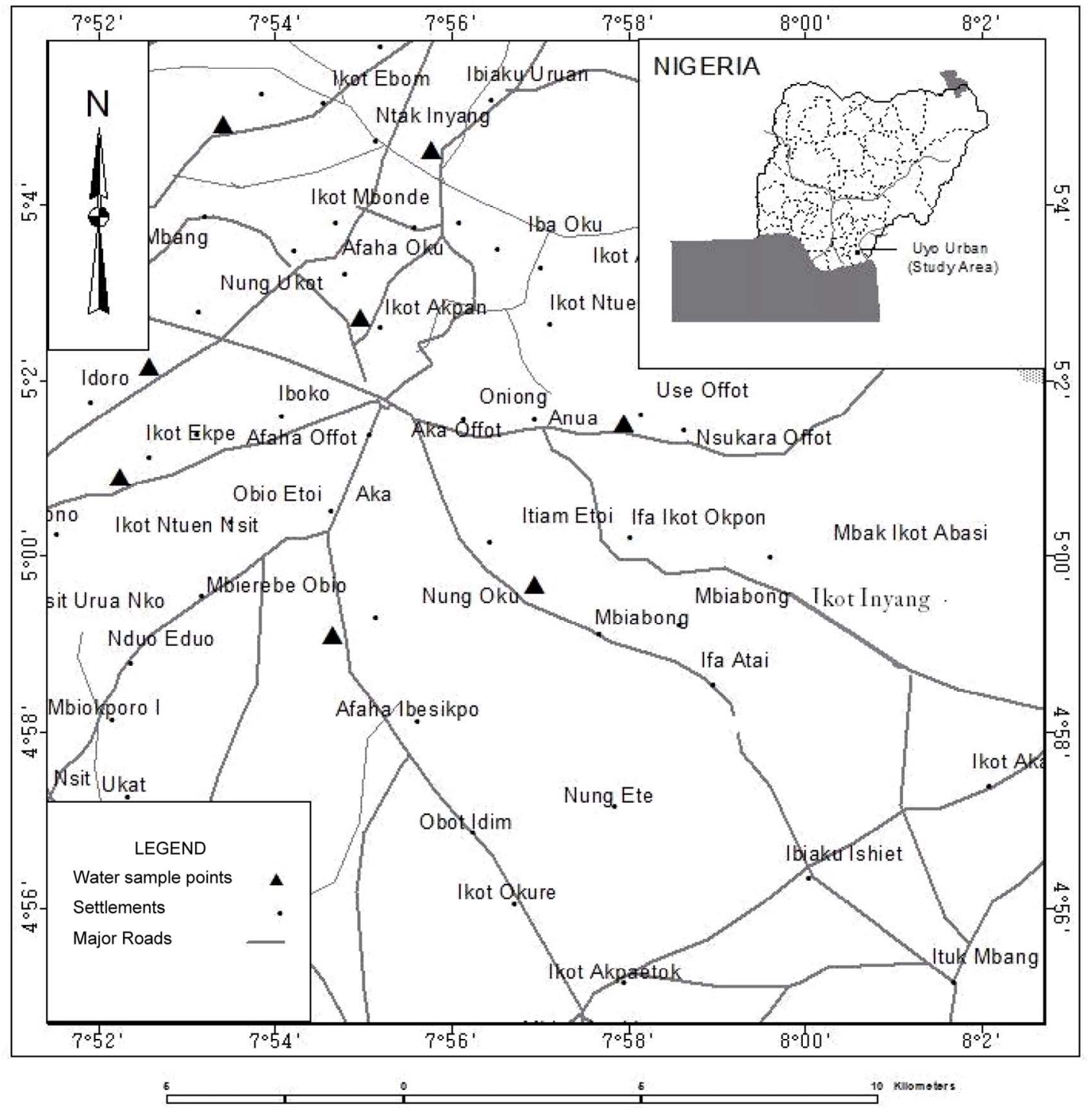

Figure 1. Locations of wells on the map of Uyo urban. 
The study area is located within the lowland coastal plain region of Nigeria. It has, on the average, a flat terrain of 61 meters above mean sea level (amsl), except in the Northern sides where 50 meters deep Ikpa river valley breaks the monotony. A close study of the area indicates that $90 \%$ of the town slopes to the South while the remaining portion slopes towards the Ikpa valley [4]. The virtually flat nature of the town has adversely affected the drainage of the town and its physical development. The stabilized ground surface has greatly increased the rate of rainfall infiltration into the ground. In some locations, wells are sited near waste dumps with little or no consideration to the possibility of the groundwater contamination through seepage.

The aluvial deposits of the late tertiary age from homogenous rock structures and sandstones, shales and clay have resulted in a physiographic region underlined by coastal plain sand. The resultant ferralitic soils are rich in free iron but low mineral reserves. The specific ferralitic soil type is brownish, porous, acidic, highly leached and relatively infertile [4].

Geologically, Uyo belongs to the area classified as coastal plain sands known as the Benin formation [5]. The Benin formation is the upper most unit of the Niger Delta complex and overlies the Agbada formation. The coastal plain sands are made of alternating sequences of gravels and sands of different grain sizes, silt, clay and alluvium. According to Edet and Okereke [6], Benin formation comprises of sediments whose age is from tertiary to recent. The Benin formation consists of finemedium coarse grained sands which are sometimes poorly sorted [5].

\section{Methodology}

Groundwater quality data were collected from the Quality Control Laboratory of the Akwa Ibom State Water Company. Water quality data for 8 locations spread across Uyo urban were used. A total of nine parameters were used, for a period of five years (2005-2009), to analyze the yearly variations.

The map of the area was registered into the ILWIS 2.2 software via the steps of scanning, import, creation of coordinate system and geo-referencing. The next step was the digitization of the various spatial features i.e. well location, soil sampling sites, land use activity, spot height and contour lines. Contour lines and spot height information were used to prepare the digital elevation model (DEM) of the study area, which was further classified by slicing operation. Piezometic map and digital elevation model was used to prepare the depth to water layer. Then all these maps were integrated into the software for further analysis and presentation of results.

\section{Results and Discussion}

The chemical quality data used for the study were conductivity, sulphate, chloride, total solids, total dissolved solids, and suspended solids. Most of the wastes generated from this area is disposed on land which percolate through the soil strata and reaches the groundwater level, thereby affecting the soil and groundwater quality of the area. The physico-chemical characteristics of the area are shown in Table 1, which reveals that the area has a high TDS content. It is highly polluting in nature and affects the ecological balance of the surrounding environment. The correlation matrix operation in the software was used to assess the relationship between some pollution indicators. The result obtained from correlation matrix operation is given in Table 2, which clearly indicates that a positive correlation coefficient exists between the pollution indicators (TDS and CN, 0.8; chloride and TDS, 0.17 as well as TDS and sulphate, 0.23). This implies that there is a direct proportionality between these parameters. The correlation results are related to seasonal variation, permeability of the aquiferous layers, groundwater table variation as well as depth of shallow wells [6].

Table 1. Physico-chemical characteristics of groundwater in the study area.

\begin{tabular}{ccccc}
\hline S/No & Parameter & Minimum & Maximum & Average \\
\hline 1 & Colour in units & 1200.0 & 2060 & 1581.667 \\
2 & Conductivity( $\mu \mathrm{s} / \mathrm{cm})$ & 3500.0 & 4590 & 3956.667 \\
3 & Sulphate (mg/L) & 180.5 & 285 & 247.167 \\
4 & Chloride (mg/L) & 250.0 & 320 & 285.000 \\
5 & Potassium (mg/L) & 0.1 & 7 & 5.300 \\
6 & Iron (mg/L) & 0.1 & 11 & 7.233 \\
7 & Total solids (mg/L) & 2050.0 & 4000 & 3025.000 \\
8 & $\begin{array}{c}\text { Total dissolved } \\
\text { solids (mg/L) }\end{array}$ & 1019.0 & 3000 & 2009.500 \\
9 & Total suspended & 295.0 & 790 & 461.667 \\
\hline
\end{tabular}

Table 2. Correlation coefficient between some parameters.

\begin{tabular}{cccc}
\hline S/No & Indicator & Indicator & Correlation \\
\hline 1 & TDS & CN & 0.80 \\
2 & Chloride & TDS & 0.17 \\
3 & TDS & Sulphate & 0.23 \\
\hline
\end{tabular}


Table 3. Groundwater quality results with respect to certain significant parameters.

\begin{tabular}{|c|c|c|c|c|c|c|c|}
\hline \multirow[t]{2}{*}{ S/no } & \multirow{2}{*}{$\begin{array}{c}\text { Groundwater quality } \\
\text { Parameter }\end{array}$} & \multirow[t]{2}{*}{ Standard limit } & \multicolumn{5}{|c|}{ Percentage of concentration greater than the WHO limit } \\
\hline & & & 2005 & 2006 & 2007 & 2008 & 2009 \\
\hline 1 & TDS & $>500 \mathrm{mg} / \mathrm{L}$ & $80 \%$ & $88 \%$ & $89.0 \%$ & $90 \%$ & $99.8 \%$ \\
\hline 2. & $\mathrm{CN}$ & $>1400 \mu \mathrm{s} / \mathrm{cm}$ & $81 \%$ & $85 \%$ & $86.7 \%$ & $90 \%$ & $95.0 \%$ \\
\hline 3. & Chloride & $>250 \mathrm{mg} / \mathrm{L}$ & $47 \%$ & $49 \%$ & $51.0 \%$ & $65 \%$ & $70.0 \%$ \\
\hline
\end{tabular}

The interpolation operation was used to prepare the spatial variability maps of different ground water quality parameters, and then slicing operation was performed on each spatial variability map on the basis of prescribed standards given by WHO $[7,8]$. The results obtained from spatial variability maps of different groundwater parameters are given in Table 3 . The results indicate an increase in the percentages of parameters higher than the recommended WHO limit during the last five years.

The groundwater pollution status of an area is influenced or controlled by some factors which include topographic slope, groundwater table variation, soil porosity, permeability of the aquiferous layers, the type and quantity of waste and land use activities [1]. Cross operation was used to study the overall effects of all these data layers on the distribution of groundwater pollution. The results from cross operation indicate that the parameters in the area tend to spread laterally to form a wider plume, since the preavailing flow rate is low. The flow rate depends on the surface terrain which is opproximately flat except for some depression. Due to the flat surface, the pollutants flow out at a slow rate and there is a greater chance for infiltration of pollutants into underground surface. The underground plume also assumes a stable area and wide shape due to regular waste disposal practices. This is so because there is an enlargement of the plume as pollutants continue to be added at a point source. Besides, the depth to groundwater layer is also an important factor considered in evaluating the groundwater pollution status of an area.

\section{Conclusions}

The study has shown that Geographic Information System (GIS) software is very useful in the analysis of topographic slope, groundwater table variation, soil porosity and land use activities in the distribution of groundwater pollution in the Nigerian city of Uyo.

It has been shown too that varoius human activities generate wastes which have high organic and inorganic contents which are directly or indirectly disposed on land without any pretreatment, thereby affecting the ground- water quality. The pollutants tend to spread more laterally and at a slow flow rate because of the flat terrain of the area. This gives a greater possibility of infiltration of polluted water into the underground surface or groundwater.

\section{References}

[1] A. O. Akankpo, G. T. Akpabio and I. O. Akpabio, "Physicochemistry and Biological Properties of Ground-Water Samples from Boreholes Sited near Waste Dumps in Uyo, Southwestern Nigeria," Natural and Applied Sciences Journal, Vol. 10, No. 2, 2009, pp. 156-165.

[2] C. C. Asonye, N. P. Okolie, E. E. Okenwa and U. G. Iwuanyawu, "Some Physio-Chemical Characteristics and Heavy Metal Profile of Nigeria Rivers, Streams and Wetlands," African Journal of Biotechnology, Vol. 6, No. 5, 2007, pp. 617-624.

[3] A. N. Amadi and P. I. Olasehinde, “Application of Remote Sensing Techniques in Hydrogeological Mapping of parts of Bosso Area, Minna, North-Central Nigeria,” International Journal of the Physical Sciences, Vol. 5, No. 9, 2010, pp. 1465-1474.

[4] A. O. Akankpo and M. U. Igboekwe, "Monitoring GroundWater Contamination Using Surface Electrical Resistivity and Geochemical Methods," Journal of Water Resource and Protection, Vol. 3, No. 5, 2011, pp. 318-324. doi:10.4236/jwarp.2011.35040

[5] A. N. Ugbaja and A. E. Edet, "Groundwater Pollution near Shallow Waste Dumps in Southern Calabar, SouthEastern Nigeria,” Global Journal of Geological Sciences, Vol. 2, No. 2, 2004, pp. 199-206.

[6] A. E. Edet and C. S. Okereke, "Delineation of Shallow Groundwater Aquifers in the Coastal Plain Sand of Calabar Area Using Surface Resistivity and Hydro-Geological,” Journal of African Earth Sciences, Vol. 35, No. 3, 2002, pp. 433-441. doi:10.1016/S0899-5362(02)00148-3

[7] WHO, International Drinking Water Standards, 3rd Edition, WHO, Geneva, 2007.

[8] WHO, Background Document for Development of WHO Guidelines for Drinking Water Quality, 3rd Edition, Geneva, 2004. 